\title{
Budaya Literasi Membaca Anak Autis SDLB
}

\section{Eva Ardiana' \& Th. Cicik Sophia²}

1,2FPBS Universitas PGRI Semarang

1,2 Jalan Sidodadi Timur No 24 Semarang

'Email : evaardiana@upgris.ac.id

2Email: ciciksophia@upgris.ac.id

\begin{tabular}{|l|l|}
\hline \multicolumn{1}{|c|}{ ABSTRACT } & \multicolumn{1}{|c|}{ ABSTRAK } \\
\hline $\begin{array}{l}\text { This study aims to describe the culture of reading } \\
\text { literacy of autistic children in elementary special }\end{array}$ & $\begin{array}{l}\text { Penelitian ini bertujuan untuk mendeskripsikan } \\
\text { budaya literasi membaca anak autis Sekolah }\end{array}$ \\
schools (SDLB). Culture of Literacy in SLB adjusts to & Dasar Luar Biasa (SDLB). Budaya lierasi di SDLB \\
the conditions and situation of the children. In & menyesuaikan kondisi dan keadaan anak. Di \\
SDLB, there are various categories of children & SDLB terdapat berbagai kategori anak yang \\
who have special abilities, one of whom is an & memiliki kemampuan khusus, salah satunya \\
autistic child. This study used a qualitative & adalah anak autis. Penelitian ini menggunakan \\
approach with observation and interview as its & pendekatan kualitatif dengan teknik \\
techniques for collecting the data. Data sources & pengumpulan data berupa observasi dan \\
were obtained from autistic children and third- & wawancara. Sumber data diperoleh dari anak \\
grade teachers of SDLB Talitakum Semarang. The & autis dan guru kelas III SDLB Talitakum Semarang. \\
results showed that the culture of reading literacy & Hasil penelitian menunjukkan bahwa budaya \\
of the third-grade autistic children was carried & lierasi membaca pada anak autis kelas III \\
out with several activities i.e. (1) listening to & dilakukan dengan beberapa kegiatan yaitu: (1) \\
stories, narration, or texts, (2) reading with the & mendengarkan dongeng, cerita, atau teks, (2) \\
teacher's guide, and (3) reading as they wish. & membaca dengan panduan guru, dan (3) \\
& membaca sesuka hati. \\
Keywords: culture of literacy, reading, autism, & Kata Kunci: budaya literasi, membaca, autis, \\
SDLB. & SDLB. \\
\hline
\end{tabular}

How to Cite: Indrariani, E., \& Sophia, T. (2018). Budaya Literasi Membaca Anak Autis SDLB. Mimbar Sekolah Dasar, 5(2), 87-96. doi:http://dx.doi.org/10.17509/mimbar-sd.v5i2.7976.

PENDAHULUAN Ferguson (Wahyuningsih, 2016) menjabarkan komponen literasi yaitu Literasi Dasar (Basic Literacy), Literasi Perpustakaan (Library Literacy), Literasi Media (Media Literacy), Literasi Teknologi (Technology Literacy), dan Literasi Visual (Visual Literacy). Literasi yang komprehensif dan saling terkait ini akan menggiring seseorang untuk berkontribusi kepada masyarakatnya sesuai dengan kompetensi dan perannya sebagai warga negara global (global citizen).

Budaya literasi di Indonesia disemarakkan dengan program Gerakan Literasi Sekolah (GLS). Dalam Silvia, O., \& Djuanda, D. (2017) dinyatakan bahwa GLS ini resmi dicanangkan secara nasional melalui tiga tahap kegiatan yaitu; (1) pembiasaan, kegiatan rutin membaca setiap hari tanpa tagihan, (2) pengembangan, kegiatan pendidikan literasi sebagai ekstrakurikuler dengan tagihan tertentu, dan (3) pembelajaran, kegiatan pendidikan literasi terintegrasi ke dalam proses pembelajaran di kelas. Budaya literasi di sekolah tidak hanya dilaksanakan di sekolah umum, melainkan juga di sekolah khusus. Salah 
Eva Ardiana \& Th. Cicik Sophia, Budaya Literasi Membaca Anak Autis SDLB

satunya di Sekolah Dasar Luar Biasa (SDLB).

Dengan adanya budaya litersi di SDLB diharapkan dapat menumbuhkan minat baca anak berkemampuan khusus dan dapat meningkatkan keterampilan berbahasa anak. Keterampilan berbahasa meliputi empat macam keterampilan yaitu menyimak, membaca, menulis, dan berbicara (Yolanda, I., Nur Aeni, A., \& Sunarya, D, 2016; Haqimurosyad, A., Iswara, P., \& Aeni, A, 2017). Literasi mencakup keterampilan berbahasa dan berpikir yang menggunakan sumber pengetahuan dalam bentuk cetak atau non cetak.

Wahyuningsih (2016) menyebutkan bahwa kegiatan literasi berhubungan dengan keterampilan membaca dan menulis. Gerakan literasi di Sekolah Luar Biasa (SLB) bertujuan untuk menciptakan iklim literasi SLB yang meliputi: (1) lingkungan fisik sekolah (ketersediaan fasilitas, sarana prasarana literasi), (2) lingkungan sosial dan afektif (dukungan dan partisipasi aktif semua warga sekolah) dalam melaksanakan kegiatan literasi SLB, dan (3) lingkungan akademik (adanya program literasi yang nyata dan bisa dilaksanakan oleh seluruh warga sekolah).

Budaya literasi pada anak berkebutuhan khusus disesuaikan dengan kondisi anak dan lingkungan. Setiap anak berkebutuhan khusus itu kondisinya berbeda-beda. Meskipun demikian, budaya literasi tetap diterapkan pada anak berkebutuhan khusus, salah satunya anak autis.

Menurut Beers (Wahyuningsih, 2016), praktik-praktik yang baik dalam gerakan literasi sekolah menekankan prinsip-prinsip sebagai berikut: (1) perkembangan literasi berjalan sesuai tahap perkembangan yang dapat diprediksi, (2) program literasi yang baik bersifat berimbang, (3) program literasi berlangsung di semua area kurikulum, (4) tidak ada istilah terlalu banyak untuk membaca dan menulis yang bermakna, (5) diskusi dan strategi bahasa lisan sangat penting, dan (6) keberagaman perlu dirayakan di kelas dan sekolah.

Prinsip-Prinsip tersebut menyesuaikan kebutuhan dan karakteristik anak autis. Selain itu, kondisi sekolah juga perlu mendapatkan perhatian dalam penerapan budaya literasi. Bagaimana dan seperti apa kondisi anak dan sekolah tidak menjadikan alasan untuk tidak mengenalkan budaya literasi dalam pembelajaran di SDLB. Berat atau ringan kegiatan literasi disesuaikan dengan kebutuhan dan keadaan sekitar. Keragaman anak dan sekolah dijadikan perhatian bersama dalam literasi.

Menurut Mulyadi (2014) autis dapat diterapi dan bahkan disembuhkan. Dengan perilaku secara dini, intensif, dan optimal. Bukti kesembuhan telah banyak dijumpai secara nyata. Pada dasarnya, kesembuhan anak autis dapat disembuhkan atau tidak, ada pada 
pilihan orang tua. Masih menurut Mulyadi (2014), dalam paradigma lama: (1) autis hanya menyangkut kasus berat saja, (2) anak autis tidak dapat berkomunikasi sama sekali, (3) autis merupakan penyakit turunan, dan (4) autis tidak dapat diterapi. Sementara itu, dalam paradigma baru: (1) autis ada yang ringan bahkan sangat ringan, (2) anak autis ada yang bisa berkomunikasi meski kualitasnya kurang optimal, (3) autis bukan penyakit turunan melainkan gangguan perkembangan sejak anak lahir, dan (4) autis dapat diterapi bahkan bisa disembuhkan seperti anak-anak lain yang mampu berkomunikasi dan bersosialisasi. Oleh karena itu, orang tua perlu mengganti paradigma lama tentang autis, dengan paradigma baru.

Septiana, Yulianto,. \& Laksono (2017, p. 25) menyebutkan bahwa setiap anak memiliki kesempatan untuk mengekspresikan diri melalui kata-kata. Begitu juga anak autis sering mengucapkan kata atau kalimat sesuka hati. Kalimat atau kata yang dituturkan terkadang dari kalimat iklan yang dibaca atau yang didengar. Bahasa iklan di televisi sangat beragam. Kata atau kalimat yang ada di iklan juga beragam. Dalam satu iklan bisa menggunakan beberapa jenis bahasa sehingga kata atau kalimat yang digunakan campurcampur.

Kanner (Bonnice, 2009, p. 25-34) mengamati beberapa hal mengenai anak autis, berupa: (1) anak autis menjadi tidak mampu menjalin hubungan dengan orang lain dan dengan berbagai situasi melalui cara biasa. Kesendirian mendalam lebih mendominasi; (2) memiliki hubungan erat dengan benda mati dan dapat memainkannya dengan gembira; (3) Suara, gerak, dan semua tindakan anak autis bersifat monoton, berulang-ulang; dan (4) kosakata luar biasa dari anak autis yang bisa bicara, ingatan yang hebat tentang kejadian-kejadian beberapa tahun sebelumnya. Kemampuan fenomenal yang membuatnya mampu menghafal banyak puisi dan nama, mengingat kembali dengan tepat pola dan urutan benda.

Ada anak autis yang hanya dapat mengeluarkan suara gema-gema dari tenggorokannya. Usia 5 tahun umumnya dipandang sebagai titik tolak penting bagi kemampuan berbicara anak autis. Bila akhirnya anak autis dapat berbicara juga, maka apa yang anak autis ucapkan itu terkesan aneh dengan pola pengucapan serta intonasi yang ganjil. Kurangnya kemampuan berbicara ini ternyata tidak sebanding dengan kemampuan kognitif anak autis (Maulana, 2008, p. 11-15). Berdasarkan hal tersebut, anak autis memiliki hak yang sama dalam menerima keterampilan berbahasa. Selain itu, pada anak autis perlu adanya pengenalan dan pemahaman mengenai budaya literasi sejak dini. Di sekolah, anak autis diharapkan juga dikenalkan budaya literasi dalam berbagai mata pelajaran. 
Eva Ardiana \& Th. Cicik Sophia, Budaya Literasi Membaca Anak Autis SDLB

\section{METODE}

Penelitian ini menggunakan pendekatan kualitatif. Data penelitiannya adalah budaya membaca wacana bahasa Indonesia. Sumber data diperoleh dari anak autis dan guru kelas III SDLB Talitakum Semarang. Teknik pengumpulan data dilakukan dengan menggunakan teknik non tes berupa observasi dan wawancara. Teknik yang digunakan dalam penganalisisan data adalah deskriptif analisis.

\section{HASIL DAN PEMBAHASAN}

Setiap anak autis memiliki karakteristik yang berbeda, baik sikap, gaya, maupun dalam keterampilan membaca. Keadaan anak autis mempengaruhi kondisi dalam belajar. Hal tersebut terjadi pada anak autis di SDLB Talitakum Semarang kelas III. Di kelas tersebut ada dua anak autis yaitu D dan A. Walaupun keduanya memiliki kendala, namun anak autis memiliki hak yang sama dalam mendapatkan pendidikan. Hal ini sebagaimana dinyatakan oleh Rahayu (2014) bahwa anak autis memiliki beberapa problematika tetapi pada dasarnya setiap anak memiliki hak yang sama dalam hal pendidikan.

D adalah anak autis kelas III usia 9 tahun. D belum dapat memahami huruf dan belum dapat merangkai huruf menjadi kata meskipun usianya sudah 9 tahun. Dengan kata lain, D belum dapat membaca, karena sebagaimana menurut Rahim (2008) bahwa kemampuan membaca adalah kemampuan mengenal huruf, selanjutnya merangkainya menjadi sebuah kata, kemudian menjadi sebuah kalimat dan memahaminya. Ketidakmampuan D di usianya yang sudah sembilan tahun itu tidak dapat disamakan dengan anak normal yang usianya sama, karena anak autis adalah anak yang mengalami gangguan perkembangan. Oleh karena itu, diagnosis ditegakkan dari gejala-gejala yang tampak yang menunjukkan adanya penyimpangan dari perkembangan yang normal sesuai umurnya (Budhiman, 1997).

D memiliki daya ingat yang luar biasa. Contohnya mampu menghafal tuturan guru saat pertama kali $D$ didaftarkan di SDLB Talitakum Semarang. D dapat mengingat dengan jelas tuturan guru saat wawancara. Hal tersebut membuat guru takjub. Tuturan tersebut masih selalu diingat D. D suka mengoceh atau membeo dengan menuturkan kata sesuka hati. Tuturan yang sering diucapkan adalah tuturan iklan. D hafal kalimat iklan televisi.

A adalah anak autis kelas III usia sembilan tahun. A mengalami kesulitan berbicara. Menurut Nugraheni (2016) penyandang autisme didiagnosa mengalami gangguan perkembangan berbahasa ekspresif ataupun reseptif. Kondisi ini menunjukkan adanya gangguan pada pemahaman dan atau dalam mengekspresikan pembicaraan. Dalam kasus siswa A, keterampilan berbicaranya kurang lancar. 
Pada dasarnya, A memahami teks tetapi untuk mengungkapkan mengalami kendala. Tuturannya kurang jelas sehingga sulit dipahami. A anak yang aktif, periang, selalu senyum, dan minim bicara. A Suka menolong $D$ ketika mengalami kesulitan di kelas. Contohnya, A sering membantu $D$ menalikan tali sepatu karena $D$ belum dapat menalikan tali sepatunya sendiri. Selain itu, A juga membantu D membereskan buku setelah selesai pembelajaran.

Kedua anak tersebut memiliki karakteristik yang berbeda. Pada saat pembelajaran, guru memahami kondisi anak dan menyesuaikan materi pembelajaran berdasarkan keadaan anak. Selain belajar di kelas, anak juga menerima terapi di sekolah. Hal tersebut dilakukan agar terjadi proses yang sama antara pembelajaran dan terapi sehingga antara guru dan terapis memiliki pemahaman yang sama. Demikian pula harus ada pemahaman yang sama antara terapis dan orang tua. Orang tua harus mendampingi anak ketika terapi. Orang tua menjalankan dan melakukan hal sama yang dilakukan dan dianjurkan oleh terapis (Siwi, A.R.K, dan Anganti, N. R. N, 2017). Dalam kasus siswa $D$ dan $A$, selama proses pembelajaran dan terapi, D dan A mendapatkan bimbingan intensif dari guru untuk memahami huruf dan angka sampai anak tersebut memahami dan dapat membaca huruf atau angka hingga dapat membaca dengan benar dan lancar.
Proses pembelajaran di SDLB dilaksanakan pukul 7.00-12.00 WIB. Beberapa kegiatan dilaksanakan di kelas dan luar kelas. Guru mengajarkan empat keterampilan berbahasa yaitu menyimak, membaca, berbicara, dan menulis. Keempat keterampilan tersebut diajarkan supaya anak terampil dalam berbahasa (Kartadinata, 2012), di mana keempat keterampilan tersebut saling berhubungan (Tarigan, 2008). Keterampilan membaca diajarkan kepada anak autis setiap hari pada setiap pembelajaran.

Budaya literasi keterampilan membaca yang terjadi di kelas III dilakukan setiap hari sebelum pelajaran dimulai. Hal itu sejalan dengan Gerakan Literasi Sekolah (GSL) yang telah dicanangkan oleh pemerintah (Kemendikbud, 2016). Waktu yang digunakan untuk proses literasi membaca yaitu 30-60 menit. Buku yang dibaca adalah buku cerita. Buku cerita yang sering digunakan adalah buku dongeng dan cerita bergambar. Buku yang digunakan untuk menggali budaya literasi membaca anak autis adalah: (1) Momotaro, (2) Putri Tanabata, (3) BukU pelajaran Ruang Kelasku, (4) Si Buta dan Si Lumpuh, dan (5) Ayo Belajar Berhitung. Selain dari buku topik cerita yang dijadikan sebagai bahan diskusi dalam budaya literasi membaca adalah: (1) Persahabatan, (2) Mematuhi Peraturan, dan (3) Lingkungan Sekolah. Budaya lierasi membaca pada anak autis kelas III dilakukan dengan beberapa kegiatan yaitu: (1) mendengarkan dongeng, cerita, 
Eva Ardiana \& Th. Cicik Sophia, Budaya Literasi Membaca Anak Autis SDLB

atau teks, (2) membaca dengan panduan guru, dan (3) membaca sesuka hati.

Kemampuan membaca anak autis berbeda-beda. Berdasarkan hasil penelitian yang dilakukan oleh Putra, R.M, Iswari, M, dan Irdamurni (2015) ada anak yang sudah mampu membaca beberapa suku kata dan kalimat namun belum bisa memahami makna atau maksud dari kalimat yang dibaca. Ada juga yang belum dapat membaca atau mengalami kesulitan membaca maka proses literasi terjadi antara guru dan siswa. Guru membacakan cerita atau dongeng kemudian anak mendengarkan. Setelah kegiatan menyimak, dilakukan tanya jawab. Kegiatan ini dilakukan untuk mengetahui sejauh mana daya ingat dan konsentrasi anak autis serta untuk mengukur tingkat pemahaman anak terhadap bacaan yang disimaknya.

Melalui kegiatan menyimak, anak dituntut untuk dapat memahami isi suatu bahan simakan yang diperolehnya dengan baik (Lestari, T., Aeni, A., \& Iswara, P. (2016). Dengan kegiatan tanya jawab akan diketahui mana anak yang memperhatikan dan mana yang tidak. Dalam Tanya jawab, pertanyaan yang diberikan adalah pertanyaan yang berkaitan dengan cerita. Misalnya, siapakah tokoh cerita tadie Dimana peristiwa tersebut terjadie Siapakah yang jahat? siapakah tokoh yang memiliki karakter baik? Apa yang dilakukan tokoh $X$ ? mengapa tokoh $X$...?

Kegiatan yang dilakukan setelah membaca atau menyimak bacaan cerita guru adalah menceritakan kembali. Anak menceritakan kembali cerita yang sudah disimak. Kegiatan ini sebagaimana yang dianjurkan oleh Iswara (2016) bahwa dalam pembelajaran menyimak anak diharapkan mampu mengemukakan kembali hasil simakan. Anak belajar kembali mengungkapkan cerita yang sudah disimak. Hal itu dilakukan untuk mengetahui daya ingat anak dan konsentrasi anak ketika memperhatikan bacaan cerita. Budaya literasi membaca ini merupakan gabungan antara keterampilan membaca dengan keterampilan menyimak. Meskipun anak menyimak tetapi anak juga belajar bagaima membaca cerita.

Selain guru yang membacakan cerita, kadang-kadang literasi membaca juga dilakukan oleh anak sendiri. Anak membaca cerita berdasarkan gambar yang ada dalam buku. Anak berimajinasi mengenai gambar yang ada dalam buku. Hal ini merupakan variasi dalam kegiatan membaca. Guru memberikan kebebasan berimajinasi pada anak untuk membaca buku walaupun anak membaca berdasarkan gambar yang ada dalam buku. Ada cerita yang dibacakan guru dan ada juga yang dibacakan siswa. Hal tersebut untuk membuat anak antusias dan konsentrasi memerhatikan bacaan, 
dan agar anak tidak bosan atau jenuh sehingga budaya literasi ini dapat dilakukan dua arah atau lebih.

Kegiatan membacakan cerita ini akan membuat anak tertarik jika cerita yang dibacakan adalah cerita baru dan belum pernah didengar. Ada juga anak yang suka dengan satu cerita yang telah dibacakan atau diperdengarkan. Bagi anak dengan kondisi ini ia akan meminta untuk dibacakan atau diperdengarkan kembali.

Ada hal yang menarik pada pembacaan cerita. Anak melihat dari cover buku. Kemudian melihat isinya. Anak tertarik jika guru membacakan cerita bergambar. Selain teks juga ada gambar yang menyertainya. Anak akan membuka buku tersebut. Meskipun anak mengalami kesulitan membaca teks, anak akan mencoba membaca gambar yang ada dalam buku. Gambar yang ada dalam buku berkesinambungan dan gambar tersebut menggambarkan cerita yang ada dalam buku. Anak belajar memaknai gambar yang ada dalam buku cerita bergambar. Anak akan menanyakan kepada guru mengenai gambar tersebut jika anak mengalami kesulitan. Contohnya, ini gambar apa? Ini siapa? Apa ini?

Kegiatan membaca pada anak autis masih dipandu guru. Anak menirukan tuturan guru. Tiruan ini dilakukan pada kegiatan pembacaan huruf, angka, kata dan kalimat. Anak diajarkan untuk mengenal huruf dan angka kemudian diminta untuk menirukan berdasarkan instruksi guru. Peniruan ini dilakukan beberapa kali sampai anak dapat mengucapkan bunyi dengan benar dan baik. Hal itu dilakukan beberapa kali karena anak autis kesulitan menirukan beberapa bunyi mulai dari kejelasan sampai kelantangan suara. Ada anak menirukan dengan suara lirih. Ada juga yang bunyi suaranya kurang jelas.

Berdasarkan uraian di atas budaya literasi membaca anak autis kelas III dilakukan dengan cara menyimak cerita, dongeng, atau teks dan mendengarkan rekaman cerita dari guru. Proses membaca dilakukan dengan cara menirukan kata atau kalimat dari guru. Tiruan ini dilakukan pada anak autis yang mengalami kesulitan membaca.

Anak autis sangat unik dan khas. Kekhasan pada anak autis menjadi daya tarik sendiri bagi orang yang ada di sekitarnya. Tidak semua orang dapat memahami tuturan anak autis. Proses pembelajaran yang diterima anak autis di sekolah ternyata berlaku sama untuk anak yang lain meskipun kondisi atau keadaannya berbeda. Maksudnya materi yang diterima sama meskipun cara menerimanya berbeda. Sebagian orang kurang memahami tuturan anak autis. Ocehan yang terkadang kurang bermakna dianggap aneh atau Iucu. Meskipun dalam kondisi yang sama yaitu 
Eva Ardiana \& Th. Cicik Sophia, Budaya Literasi Membaca Anak Autis SDLB

sama-sama autis, ternyata anak autis memiliki keragaman.

Budaya literasi keterampilan menulis kadang-kadang dilakukan bersamaan dengan keterampilan membaca. Setelah anak membaca kemudian diminta untuk menulis. Anak menulis sesuai dengan yang ada dalam buku atau berdasarkan instruksi dari guru. Keterampilan menulis di sini, sesuai dengan tahapannya yaitu berada pada keterampilan menulis permulaan. Menurut Aqmarina, N., Aeni, A., \& Djuanda, D. (2016) menulis permulaan merupakan pembelajaran menulis untuk siswa kelas rendah. Menulis permulaan diajarkan untuk siswa kelas I-III (Halimah, H., Djuanda, D., \& Aeni, A., 2016).

Budaya literasi menulis kalimat bahasa Indonesia pada anak autis SDLB kelas III masih perlu mendapatkan perhatian guru dan orang tua. Pendampingan dan bimbingan orang tua dan guru sangat diperlukan untuk menjadikan anak autis suka atau terampil menulis sehingga tidak mengalami hambatan dalam berkomunikasi. Sebagaimana dinyatakan oleh Rochmah (2016) bahwa peran orang tua untuk meningkatkan kemampuan komunikasi adalah dengan peran pendampingan.

Budaya literasi bahasa Indonesia anak autis SDLB belum maksimal. Hal itu terlihat pada proses literasi membaca anak autis. Anak masih belum dapat membaca dengan lancar, bahkan ada yang belum dapat membaca. Oleh karena itu, budaya literasi membaca diatasi dengan menyimak, yaitu anak autis menyimak bacaan cerita. Meskipun demikian, anak autis tetap melaksanakan literasi membaca. Anak belajar bagaimana cara membaca cerita baik dari buku cerita maupun cerita bergambar. Dengan menggunakan buku cerita bergambar, budaya literasi membaca anak autis terjadi dengan proses imajinasi. Anak autis berimajinasi membaca gambar yang ada dalam buku cerita bergambar. Anak mencoba merangkai gambar yang satu dengan yang lain untuk digabungkan menjadi sebuah cerita. Hal ini mengajarkan pada anak autis menggunakan logika dan pikirannya untuk memahami gambar sehingga menjadi cerita yang utuh.

\section{SIMPULAN}

Budaya literasi membaca pada anak autis terjadi pada proses pembelajaran di kelas. Budaya literasi pun perlu diterapkan di sekolah pada setiap mata pelajaran. Literasi membaca pada anak autis bias dilakukan pada awal pembelajaran. Pada anak autis kelas III dengan kondisi anak yang belum lancar membaca dan kesulitan berbicara, budaya literasi membaca masih perlu dipandu guru. Kegiatan membaca pun perlu dilakukan oleh guru kemudian anak menyimak pembacaan teks atau wacana dari guru. Bahan bacaan yang menarik bagi anak autis adalah cerita atau dongeng. 


\section{REFRENSI}

Aqmarina, N., Aeni, A., \& Djuanda, D. (2016). MENINGKATKAN KETERAMPILAN MENULIS PENGUMUMAN MELALUI PENERAPAN MODEL GENRE BASED WRITING DENGAN PERMAINAN SCRAMBLE. Jurnal Pena llmiah, 1 (1), 461470. doi:http://dx.doi.org/10.23819/pi.vlil.29 75.

Budhiman, M. (1997). "Tata Laksana terpadu pada Autisme". Makalah pada Symposium Tata Laksana Autisme: gangguan perkembangan pada anak. Yayasan Autisme Indonesia. Jakarta.

Halimah, H., Djuanda, D., \& Aeni, A. (2016). PENERAPAN METODE SQ3R DAN PERMAINAN STABILO KALIMAT UNTUK MENINGKATKAN KEMAMPUAN MEMBACA DALAM MENYIMPULKAN ISI CERITA ANAK. Jurnal Pena Ilmiah, 1(1), 651-660.

doi:http://dx.doi.org/10.23819/pi.v1i1.29 97.

Haqimurosyad, A., Iswara, P., \& Aeni, A. (2017). PENERAPAN TEKNIK THINK-PAIRSHARE UNTUK MENINGKATKAN KETERAMPILAN MENYIMAK SISWA PADA MATERI CERITA PERISTIWA. Jurnal Pena Ilmiah, 2(1), 101-110. doi:http://dx.doi.org/10.23819/jpi.v2i1.95 31.

Iswara, P. (2016). PENGEMBANGAN MATERI AJAR DAN EVALUASI PADA KETERAMPILAN MENDENGARKAN DAN MEMBACA. Mimbar Sekolah Dasar, 3(1), 89-97.

doi:http://dx.doi.org/10.17509/mimbarsd.v3il.2359

Kartadinata, S. (2012). Bahan ajar bahasa Indonesia SD/MI. Tidak Diterbitkan.

Kemendikbud. (2016). Desain Induk Gerakan Literasi Sekolah. Jakarta: Dirjen Dikdasmen Kemendikbud.

Lestari, T., Aeni, A., \& Iswara, P. (2016). PENERAPAN METODE COCOA UNTUK MENINGKATKAN KETERAMPILAN MENGOMENTARI TOKOH CERITA/ DONGENG ANAK. Jurnal Pena Ilmiah, 1 (1). $\quad$ 531-540. doi:http://dx.doi.org/10.23819/pi.v1i1.29 98.

Maulana, M. (2008). Anak Autis. Jogjakarta: Katahati.

Mulyadi, K dan Setiadi, R. (2014). Autism IS Curable. Jakarata: PT Gramedia.
Nugraheni, S. (2016). Menguak Belantara Autisme. Buletin Psikologi, 20(1-2), 9-17. /*doi:http://dx.doi.org/10.22146/bpsi.11 944*/ doi:https://doi.org/10.22146/bpsi.11944

Putra, R.M, Iswari, M, dan Irdamurni. (2015). Meningkatkan Kemampuan Membaca Pemahaman Kalimat Sederhana Bagi Anak Autis Melalui Media Flip Chart. EJupekhu (Jurnal Ilmiah Pendidikan Khusus), 4(1), 109-119. http://ejournal.unp.ac.id/index.php/jup ekhu

Rahayu, F. (2014). Kemampuan Komunikasi Anak Autis Dalam Interaksi Sosial (Kasus Anak Autis di Sekolah Inklusi, SD Negeri Giwangan Kotamadya Yogyakarta. (Skripsi). Program Studi Pendidikan Luar Biasa Jurusan Pendidikan Luar Biasa Fakultas IImu Pendidikan Universitas Negeri Yogyakarta, Yogyakarta. file://C:/Users/hp/Downloads/541611859-1-SM.pdf

Rahim, F. (2008). Pengajaran Membaca di Sekolah Dasar. Jakarta: PT Bumi Aksara.

Rohmah, I.M. (2016). Peran Orang tua Untuk Meningkatkan Komunikasi Anak Autis. (Skripsi). Fakultas Psikologi. Universitas Islam Negeri Maulana Malik Ibrahim, Malang. http://etheses.uinmalang.ac.id/5216/1/12410105.pdf

Septiana, Yulianto, Laksono. (2017) Ketidakselarasan Tuturan Anak Autis. FKIP e-PROCEEDING, [S.I.], p. 23-34, july 2017. Available at: <http://jurnal.unej.ac.id/index.php/fkipepro/article/view/4850 (hal 23-33).

Silvia, O., \& Djuanda, D. (2017). MODEL LITERATURE BASED DALAM PROGRAM GERAKAN LITERASI SEKOLAH. Mimbar Sekolah Dasar, 4(2), 160-171. doi:http://dx.doi.org/10.23819/mimbarsd.v4i2.7799

Siwi, A.R.K, dan Anganti, N. R. N. (2017). Strategi Pengajaran Interaksi Sosial Kepada Anak Autis. Indigenous: Jurnal Ilmiah Psikologi, 2 (2), 184-192. file:///C:/Users/hp/Downloads/570313310-1-PB\%20(1).pdf.

Tarigan, H. G. (2008). Membaca Sebagai Suatu Keterampilan Berbahasa. Bandung: Angkasa.

Wahyuningsih et al. (2016). Panduan Gerakan Literasi Sekolah di Sekolah Luar Biasa. Jakarta: Direktorat Pembinaan Pendidikan Khusus dan Layanan Khusus 
Eva Ardiana \& Th. Cicik Sophia, Budaya Literasi Membaca Anak Autis SDLB

Direktorat Jenderal Pendidikan Dasar dan Menengah Kementerian Pendidikan dan Kebudayaan. http://perpustakaan.kemdikbud.go.id:9 090/56/1/Panduan-Gerakan-LiterasiSekolah-di-SLB.pdf.

Yolanda, I., Nur Aeni, A., \& Sunarya, D. (2016). PENERAPAN METODE TURNAMEN MEMBACA UNTUK MENINGKATKAN KETERAMPILAN SISWA DALAM MENEMUKAN INFORMASI MELALUI MEMBACA MEMINDAI. Jurnal Pena Ilmiah, $\quad 1(1), \quad$ 1081-1090. doi:http://dx.doi.org/10.23819/pi.vli1.30 28. 